\title{
Evaluasi Metode Pendugaan Laju Evapotranspirasi Standar (ETo) Menggunakan Bahasa Pemograman Visual Basic Microsoft Excel di Kabupaten Nagan Raya Aceh
}

\author{
(Evaluation of Standard Evapotranspiration Rate Estimation Method (ETo) \\ Using Microsoft Excel Visual Basic Programming Language in Nagan Raya \\ Aceh District)
}

\author{
Adlan $^{1 *}$, Budi Indra Setiawan ${ }^{1}$, Chusnul Arif ${ }^{1}$, dan Satyanto Krido Saptomo ${ }^{1}$ \\ ${ }^{1}$ Departemen Teknik Sipil dan Lingkungan, Fakultas Teknologi Pertanian, Institut Pertanian Bogor. \\ J1. Raya Dramaga, Kampus IPB Dramaga, PO BOX 220, Bogor, Jawa Barat, Indonesia \\ Penulis Korespondensi: adlanrusman48@gmail.com
}

\begin{abstract}
Estimation of evaporation rate is needed in hydrological data, especially in irrigation and drainage planning data. The method for estimating the evapotranspiration rate recommended by FAO is the Penman - Monteith method, however apart from this method there are still several methods that can be used if the data obtained in the field are different. Evaluation of the method of estimating the rate of evapotranspration is expected to help in choosing the right method when different data is obtained, so with this evaluation, we can see the accuracy of the methods. The methods that are closest to accuracy with the Penman - Monteith method are Hargreaves, Makkink, Turc, Blaney-Cridlle and Penman. If ordered based on the ranking of the evaluation results, the method that is closest to the Penman - Monteith method is Hargreaves, because of all the evaluation variabels Hargreaves has the best evaluation value. While the closest model based on the best $R^{2}$ value is the Jensen-Haise model, but the error value of this model is very high.
\end{abstract}

Keywords: Evapotranspiration, Method, Penman - Monteith, Regression.

\section{PENDAHULUAN}

Metode pendugaan laju evapotranspirasi saat ini bisa ditentukan oleh berbagai macam model evapotraspirasi (Runtunuwu et al, 2008), sehingga dalam menentukan pendugaan laju evapotraspirasi membutuhkan metode yang tepat dan sesuai terhadap data yang didapatkan dengan melakukan sebuah evaluasi terhadap metode perhitungan komponen hidrologi, khususnya laju evapotranspirasi. Adanya evaluasi metode laju evapotraspirasi ini diharapkan bisa menjadi pertimbangan dalam penentuan penggunaan alat pengukuran yang menjadi prioritas utama untuk tingkat akurasi yang baik.
Berengena dan Gavilan (2005) menguji berbagai metode pengukuran laju evapotranspirasi yang telah dilakukan sebelumnya di bagian Selatan Spanyol, daerah dengan adveksi yang kuat. Hasilnya menunjukkan metode Penman dengan menyesuaikan fungsi angin menurut kondisi lokal menghasilkan pendekatan terbaik terhadap laju evapotranspirasi hasil lisimeter, yang diikuti dengan metode Penman-Monteith versi FAO 56. Steduto et al. (2003) menguji metode FAO 56 di bagian Selatan Italia yang memiliki iklim Mediterania semi-arid hasilnya menunjukkan metode FAO 56 paling baik dalam menduga laju evapotranspirasi harian, tetapi cenderung over estimate di musim 
dingin ketika laju evapotranspirasi rendah dan under estimate di musim panas ketika laju evapotranspirasi tinggi.

Temesgen et al. (2005) juga menguji metode FAO 56 di California, USA dan hasilnya menunjukkan korelasi yang baik dengan laju evapotranspirasi yang diukur pada 37 stasiun iklim di wilayah ini, sedangkan Fibriana et al. (2018) metode FAO 56 di Indonesia sangat dipengaruhi faktor suhu, radiasi matahari, dan kecepatan angin. Hal ini diperkuat oleh Saidah et al. (2020) dimana metode FAO 56 digunakan sebagai kalibrasi terhadap persamaan Thornthwaite dan Evaporasi Panci untuk wilayah terbatas di indonesia.

Berdasarkan hasil pengujian yang telah dilakukan sebelumnya yang sudah di jelaskan pada paragraf di atas, metode Penman-Monteith rekomendasi FAO 56 adalah metode yang memiliki hasil terbaik (Berengena dan Gavilan 2005; Steduto et al. 2003; Temesgen et al. 2005; Fibriana et al. 2018; dan saidah et al. 2020) dalam menentukan laju evapotranspirasi, sehingga melalui pertimbangan itu maka evaluasi dalam pendugaan laju evapotraspirasi akan di evaluasi dengan metode Penman Monteith.

Suprayogi, et al. (2003) juga pernah melakukan mengkajian data iklim di Sub DAS Ciriung Kabupaten Serang, yang luasnya sekitar 118,01 ha dengan tujuh model evapotranspirasi potensial untuk mendapatkan model yang efisien dan sederhana, yaitu Penman-Monteith, Penman, JensenHaise, Hargreaves, Radiasi, Turc, dan Makkink. Hasil yang didapatkan model evapotranspirasi sederhana hanya membutuhkan dua parameter data iklim seperti model Turc, Hargreaves, dan Model Jensen-Haise, sedangkan model Penman-Monteith membutuhkan minimal enam data parameter.
Kebutuhan data laju evapotranspirasi sangat dibutuhkan dalam banyak hal, bersarkan penempatan stasiun klimatologi BMKG masih memiliki keterbatasan dibeberapa titik penempatan (dataonline.bmkg.go.id), khususnya wilayah Aceh dimana bagian tengah wiliyah aceh masih belum memiliki stasiun klimatologi, sehingga jika ingin mengetahui laju evapotranspirasi dengan metode Penman - Monteith FAO 56 membutuhkan minimal enam alat pengukur parameter iklim (Suprayogi, et al. 2003) di wilayah tengah Aceh seperti Aceh Tengah, Bener Meriah, Dan Gayo Lues, jika adanya evaluasi model model yang paling korelasi dengan model Penman - Monteith, maka untuk mendapatkan data laju evapotranspirasi bisa hanya dengan menggunakan alat pengukur iklim yang lebih sedikit sebagai parameter iklim dalam penentuan laju evapotranspirasi.

Adapun stasiun klimatologi BMKG yang paling mendekati wilayah tengah Aceh yaitu stasiun klimatologi Cut Nyak Dien yang berada di Kabupaten Nagan Raya Aceh (dataonline.bmkg.go.id), sehingga dengan adanya evaluasi dari data klimatolgi Cut Nyak Dien ini dapat membantu pendekatan yang lebih akurat terhadap iklim di wilayah tengah Aceh seperti Aceh Tengah, Bener Meriah, dan Gayo Lues.

\section{METODOLOGI}

$\begin{array}{ccr}\text { Evaluasi } & \text { metode } & \text { laju } \\ \text { evapotranspirasi } & \text { standar } & \text { ini }\end{array}$ menggunakan beberapa persamaan model evapotranspirasi, diantaranya model Blaney Criddle, Linacre, Kharrufa, Romanenko, Hargreaves, Makkink, Turc, Jensen-Haise, Penman, Penman-Monteith. Persamaan dari setiap model-model tersebut 
dibahasakan kedalam bahasa program visual basic, sehingga menjadi sebuah model didalam software Microsoft Excel. Adapun data yang digunakan adalah data dari stasiun klimatologi Cut Nyak Dien (4.05 LS - 96.25 BT) Kabupaten Nagan Raya Aceh.

Data-data iklim (2010-2019) yang digunakan adalah data harian dari suhu maksimum dan minimum udara, kelembaban udara, kecepatan angin, lama penyinaran dan data hujan dari stasiun klimatologi Cut Nyak Dien Kabupaten Nagan Raya Aceh. Persamaan Motode Pendugaan Evapotranspirasi yang digunakan diantaranya sebagai berikut:

1. Blaney H.F., dan W. D. Criddle. (1962):

$$
E T_{p}=p\left(0.457 \cdot T_{a}+8.128\right)
$$

Keterangan:

$E T_{p} \quad=$ Evapotranspirasi

$$
\begin{aligned}
& \text { Potensial }\left(\frac{\mathrm{mm}}{\text { hari }}\right) \\
\mathrm{p}= & \text { Mean daily percentage } \\
& \text { of total annual daytime } \\
& \text { hours } \\
\mathrm{Ta} \quad & \text { Suhu Rata }- \text { rata }^{\circ} \mathrm{C}
\end{aligned}
$$

2. Linacre, E. and Hoobs, J. (1977):

$$
E T_{o}=\frac{\left(\frac{500 T_{m x}}{100-L}\right)+15\left(T a-T_{m n}\right)}{80-T a} .
$$

Keterangan:

$E T_{p} \quad=$ Evapotranspirasi

$$
\begin{array}{ll} 
& \text { Potensial }\left(\frac{m m}{\text { hari }}\right) \\
\mathrm{L} & =\text { Latitude } \\
\mathrm{Tmx} & =\text { Suhu Maksimum }{ }^{\circ} \mathrm{C} \\
\mathrm{Tmn} & =\text { Suhu Minimum }{ }^{\circ} \mathrm{C} \\
\mathrm{Ta} & =\text { Suhu Rata }-\operatorname{rata}^{\circ} \mathrm{C}
\end{array}
$$

3. Kharrufa, N. (1985):

$$
E T=0.34 \cdot p T_{a}^{1.3}
$$

Keterangan:

$E T_{p} \quad=$ Evapotranspirasi

$$
\begin{aligned}
& \text { Potensial }\left(\frac{\mathrm{mm}}{\text { hari }}\right) \\
\mathrm{p}= & \text { Mean daily percentage } \\
& \text { of total annual daytime } \\
& \text { hours } \\
\mathrm{Ta} \quad & \text { Suhu Rata }-\operatorname{rata}^{\circ} \mathrm{C}
\end{aligned}
$$

4. Romanenko V. A. (1961):

$$
E T=0.0018(25+T a)^{2}(100-R H) .
$$

Keterangan:

$E T_{p} \quad=$ Evapotranspirasi Potensial

$$
\begin{aligned}
& \left(\frac{m m}{h a r i}\right) \\
\mathrm{RH} & =\text { Kelembaban Udara }(\%) \\
\mathrm{Ta} & =\text { Suhu Rata }-\operatorname{rata}^{\circ} \mathrm{C}
\end{aligned}
$$

5. Hargreaves, G. H. (1982):

$\mathrm{ET}_{p}=\mathrm{K} \sqrt{\mathrm{Tmx}-\mathrm{Tmn}}\left(\mathrm{T}_{a}+18.8\right) \operatorname{Ra}(\mathrm{L}, \mathrm{J}) \cdot(5)$

Keterangan:

$E T_{p} \quad=$ Evapotranspirasi Potensial

$$
\begin{aligned}
& \left(\frac{m m}{\text { hari }}\right) \\
\mathrm{K}= & 0.000939 \\
\mathrm{Tmx}= & \text { Suhu Maksimum }{ }^{\circ} \mathrm{C} \\
\mathrm{Tmn}= & \text { Suhu Minimum }{ }^{\circ} \mathrm{C} \\
\mathrm{Ta}= & \text { Suhu Rata }-\operatorname{rata}^{\circ} \mathrm{C} \\
\mathrm{Ra}= & \text { Radiation on top of the } \\
& \text { atmosfer }\left(\frac{M J}{m^{2} / \text { hari }}\right)
\end{aligned}
$$

6. Makkink, G. F. (Capece et.al. 2002):

$E T=0.61 \frac{\Delta}{\Delta+\gamma} \frac{R_{S}}{\alpha}-$

Keterangan:

$E T_{p} \quad=$ Evapotranspirasi Potensial $\left(\frac{m m}{\text { hari }}\right)$ 
$\Delta \quad=$ Slope Vapor Pressure curve $\left(\frac{k P a}{{ }^{\circ} \mathrm{C}}\right)$

$\gamma \quad=$ Psychometric Constant $\left(\frac{k P a}{{ }^{\circ} \mathrm{C}}\right)$

7. Turc, L. (Capece et.al. 2002):

Saat RH di bawah 50\% rumus yang digunakan:

$$
E T=0.013 \frac{T_{a}}{T_{a}+15}\left(R_{S}+50\right) .
$$

Saat RH di atas $50 \%$ rumus yang digunakan:

$E T=0.013 \frac{T_{a}}{T_{a}+15}\left(R_{S}+50\right)\left(1+\frac{50-R H}{70}\right) .$.

Keterangan:

$E T_{p} \quad=$ Evapotranspirasi Potensial

$$
\begin{aligned}
& \left(\frac{m m}{\text { hari }}\right) \\
\text { Rs }= & \text { Radiasi Matahari } \\
& \left(\frac{M J}{m^{2} / \text { hari }}\right) \\
\mathrm{Ta}= & \text { Suhu Rata }- \text { rata }^{\circ} \mathrm{C} \\
\mathrm{RH}= & \text { Kelembaban Udara }(\%)
\end{aligned}
$$

8. Jensen, M.E. and H.R, Haise. (1963):

$$
E T_{p}=C_{t}\left(T_{a}-T_{x}\right) R_{s}
$$

Keterangan:

$C_{t} \quad=$ Koefisien Temperature

$T_{a}=$ Suhu Rata - rata ${ }^{\circ} \mathrm{C}$

$T_{x}=-2.5-0.14\left(\mathrm{e}_{2}-\mathrm{e}_{1}\right)-\frac{E}{550}$

$\mathrm{E} \quad=$ Elevasi

Rs = Radiasi Matahari

$$
\left(\frac{M J}{m^{2} / \text { hari }}\right)
$$

9. Penman (Doorenbos dan Pruitt. 1997):

$$
E T_{o}=c\left[W_{x} R_{n}+(1-W) f(u)(e a-e d)\right]
$$

Keterangan:

$E T_{o}=$ Evapotranspirasi Potensial $\left(\frac{m m}{\text { hari }}\right)$

$\mathrm{W}=$ Faktor pemberat yang berkaitan dengan suhu

$R_{n} \quad=$ Radiasi netto ekivalen evaporasi $\left(\frac{M J}{m^{2} / \text { hari }}\right)$

$\mathrm{f}(\mathrm{u})$ = fungsi yang berkaitan dengan angin

$($ ea-ed $)=$ Perbedaan antara tekanan uap jenuh pada suhu udara rata - rata dengan tekanan uap aktual

c $\quad=$ Faktor Koreksi

10. Penman-Monteith (Capece et.al. 2002):

$E T_{o}: \frac{0.408 \cdot \Delta\left(R_{n}-G\right)+\gamma\left(\frac{900}{T_{\text {mean }}+273}\right) u_{2}\left(e_{s}-e_{a}\right)}{\Delta+\gamma\left(1+0.34 u_{2}\right)}$

$E T_{o}=$ Evapotranspirasi Potensial $\left(\frac{m m}{\text { hari }}\right)$

$\Delta \quad=$ Slope Vapor Pressure curve $\left(\frac{k P a}{{ }^{\circ} \mathrm{C}}\right)$

$R_{n} \quad=$ Radiasi netto ekivalen evaporasi $\left(\frac{M J}{m^{2} / \text { hari }}\right)$

$\gamma \quad=$ Psychometric Constant $\left(\frac{k P a}{{ }^{\circ} \mathrm{C}}\right)$

$($ es-ea $)=$ Perbedaan antara tekanan uap jenuh pada suhu udara rata - rata dengan tekanan uap actual

$\mathrm{u}=$ Kecepatan angin $\left(\frac{m}{\text { detik }}\right)$

Masing-masing dari nilai laju evapotraspirasi akan di bandingkan (dievaluasi) dengan metode Penman Monteith, seperti kita ketahui bahwa metode pendugaan yang direkomendasi oleh FAO- adalah Penman-Monteith. Evaluasi juga dinilai berdasarkan $\mathrm{R}^{2}$, RMSE (Root Mean Squared Error), 
MAE (Mean Absolute Error), COVARIANCE, dan LOG sebagai parameter evaluasi. Adapun persamaannya sebagai berikut:

$\mathrm{R}^{2}=1-\left[\frac{\sum(\text { ETpai-ETpmi })^{2}}{\sum(\text { ETpai-ETpa })^{2}}\right]$

$\mathrm{RMSE}=\sqrt{\frac{1}{N} \sum_{i=1}^{N}(\text { ETpai }- \text { ETpmi })^{2}}$

$\mathrm{MAE}=\frac{1}{N} \sum_{i=1}^{N} \mid$ ETpai - ETpmi $\mid$

$\mathrm{COV}=\frac{\sum(X i-X a)(Y i-Y a)}{n-1}$

$\mathrm{LOG}=\sqrt{\frac{1}{N} \sum_{i=1}^{N}(\log \text { ETpai }-\log E T p m i)^{2}}$

Kemudian berdasarkan parameter evaluasi tersebut dilakukan pembobotan yang penulis rumuskan sebagai berikut:

Overall $=A n x \frac{1}{B n}$

Keterangan:

An = nilai yang semakin tinggi nilai nya maka semakin baik

$\mathrm{Bn} \quad=$ nilai yang semakin rendah nilai nya semakin baik semakin baik
Maka didapatkan persamaan sebagai berikut:

Overall $=\left(\frac{R^{2}+R_{\text {intercept }}^{2}}{2}\right) x \frac{1}{R M S E+M A E+C O V+L O G}$

\section{HASIL DAN PEMBAHASAN}

Data pendugaan laju evapotranspirasi yang dihasilkan dari masing - masing metode memiliki nilai berbeda, namun dari beberapa metode juga memiliki hasil yang mendekati. Adapun hasil perhitungan laju evapotraspirasi harian dalam satu bulan dapat dilhat pada Tabel 1. Pada data tersebut metode yang paling mendekati adalah metode Hargreaves, Makkink, Turc, Penman dan Blaney-Cridlle. Hasil evaluasi dapat dilihat pada Tabel 2 .

Hasil evaluasi dilakukan berdasarkan beberapa khasus yaitu berdasarkan konsistensi hasil data di priode tahun tertentu, serta evaluasi ditahun kering dan tahun basah. Gambar-gambar berikut merupakan hasil dari pendugaan laju evapotraspirasi yang telah di evaluasi antara model model dengan metode Penman Monteith. 
JSIL | Adlan dkk. : Evaluasi Metade Pendugaan Laju Evapotranspirasi Standar (ETo)

Tabel 1. Laju Evapotranspirasi Januari 2019

\begin{tabular}{|c|c|c|c|c|c|c|c|c|c|c|}
\hline \multirow[b]{2}{*}{$\mathrm{J}$} & \multicolumn{10}{|c|}{ ETo (mm/hari) } \\
\hline & $\begin{array}{l}\text { Blaney- } \\
\text { Cridlle }\end{array}$ & Linacre & Kharrufa & Romanenko & Hargreaves & Makkink & Turc & Jensen-Haise & Penman & Penman-Monteith \\
\hline 1 & 5.2 & 3.5 & 6.7 & 5.3 & 4.4 & 3.2 & 3.3 & 8.6 & 2.9 & 4.1 \\
\hline 2 & 5.2 & 3.7 & 6.8 & 5.3 & 4.4 & 4.9 & 4.7 & 12.9 & 4.6 & 5.4 \\
\hline 3 & 5.3 & 3.7 & 7.0 & 6.4 & 4.5 & 4.4 & 4.3 & 11.5 & 4.1 & 5.0 \\
\hline 4 & 5.1 & 3.6 & 6.5 & 6.6 & 4.6 & 5.5 & 5.2 & 15.7 & 5.4 & 6.1 \\
\hline 5 & 5.2 & 3.9 & 6.9 & 5.9 & 4.7 & 4.9 & 4.7 & 13.5 & 4.6 & 5.7 \\
\hline 6 & 5.3 & 3.9 & 7.0 & 7.9 & 4.7 & 5.3 & 5.1 & 14.2 & 4.9 & 6.2 \\
\hline 7 & 5.2 & 4.2 & 6.9 & 5.4 & 4.8 & 4.8 & 4.6 & 14.0 & 4.4 & 5.4 \\
\hline 8 & 5.3 & 3.7 & 7.0 & 6.4 & 4.4 & 4.4 & 4.3 & 11.4 & 4.0 & 5.0 \\
\hline 9 & 5.3 & 3.8 & 7.2 & 6.6 & 4.5 & 4.0 & 4.0 & 10.4 & 3.6 & 5.0 \\
\hline 10 & 5.3 & 3.5 & 7.0 & 5.5 & 3.8 & 4.9 & 4.8 & 12.1 & 4.5 & 5.0 \\
\hline 11 & 5.2 & 3.6 & 6.7 & 2.9 & 4.0 & 4.2 & 4.1 & 11.2 & 3.9 & 4.4 \\
\hline 12 & 5.1 & 3.2 & 6.5 & 2.8 & 4.1 & 3.7 & 3.7 & 9.4 & 3.4 & 4.3 \\
\hline 13 & 5.2 & 4.2 & 6.8 & 4.8 & 4.8 & 3.8 & 3.8 & 12.1 & 3.5 & 5.0 \\
\hline 14 & 5.2 & 3.5 & 6.9 & 4.9 & 4.1 & 5.4 & 5.2 & 13.8 & 5.1 & 5.6 \\
\hline 15 & 5.2 & 3.3 & 6.8 & 5.3 & 4.1 & 4.3 & 4.2 & 10.7 & 4.0 & 4.9 \\
\hline 16 & 5.2 & 3.4 & 6.8 & 5.8 & 3.9 & 2.0 & 2.3 & 5.3 & 1.7 & 3.1 \\
\hline 17 & 5.2 & 3.6 & 6.9 & 5.9 & 4.3 & 3.1 & 3.2 & 8.2 & 2.8 & 4.3 \\
\hline 18 & 5.2 & 3.5 & 6.9 & 4.9 & 4.0 & 5.4 & 5.2 & 13.8 & 5.2 & 5.4 \\
\hline 19 & 5.3 & 4.2 & 7.0 & 5.9 & 4.8 & 2.8 & 2.9 & 8.4 & 2.4 & 4.3 \\
\hline 20 & 5.0 & 2.6 & 6.2 & 1.8 & 3.3 & 3.9 & 3.8 & 9.1 & 3.6 & 4.1 \\
\hline 21 & 4.9 & 2.4 & 5.9 & 1.7 & 3.5 & 2.0 & 2.2 & 5.0 & 1.8 & 3.0 \\
\hline 22 & 5.2 & 3.9 & 6.8 & 9.1 & 4.7 & 2.2 & 2.4 & 6.6 & 2.0 & 3.6 \\
\hline 23 & 5.2 & 4.0 & 6.9 & 4.4 & 4.9 & 5.3 & 5.1 & 15.4 & 5.0 & 5.9 \\
\hline 24 & 5.3 & 3.7 & 7.0 & 5.4 & 4.4 & 5.2 & 5.1 & 13.6 & 4.9 & 5.7 \\
\hline 25 & 5.2 & 3.4 & 6.8 & 5.8 & 4.3 & 4.9 & 4.8 & 12.7 & 4.7 & 5.3 \\
\hline 26 & 5.3 & 3.8 & 7.1 & 6.5 & 4.3 & 4.2 & 4.2 & 11.1 & 3.9 & 4.7 \\
\hline 27 & 5.2 & 3.2 & 6.7 & 2.4 & 4.1 & 3.6 & 3.6 & 9.1 & 3.3 & 4.2 \\
\hline 28 & 5.3 & 3.8 & 7.0 & 8.4 & 4.5 & 2.3 & 2.5 & 6.4 & 2.0 & 3.8 \\
\hline 29 & 5.2 & 3.5 & 6.8 & 6.3 & 4.2 & 3.2 & 3.3 & 8.5 & 2.9 & 4.2 \\
\hline 30 & 5.3 & 3.7 & 7.0 & 5.9 & 4.4 & 4.6 & 4.5 & 12.1 & 4.3 & 5.2 \\
\hline 31 & 5.3 & 3.8 & 7.1 & 7.0 & 4.2 & 4.7 & 4.7 & 12.5 & 4.5 & 5.0 \\
\hline
\end{tabular}

Manik, et al. (2012) rendahnya kualitas data dapat disebabkan beberapa faktor seperti kurang telitinya pengamat, kurang terpeliharanya instrumen pengamatan atau kurang terpeliharanya lingkungan sekitar stasiun atau karena beragamnya unsur-unsur iklim yang saling mempengaruhi laju evapotranspirasi. Adanya pemilihan metode yang dapat menjadi pembanding hasil pengamatan sebagai evaluasi kesalahan maka kesalahan-kesalahan tersebut dapat diminimalisir dengan data hasil evaluasi dengan mempertimbangkan variabel data yang didapatkan.

Tabel 2. Nilai R2 antara Model - model dengan Model Penman - Monteith di Hujan 4200 $-4600 \mathrm{~mm} / \mathrm{tahun}$

\begin{tabular}{cccccccccc}
\hline YY & $\begin{array}{c}\text { Blaney- } \\
\text { Cridlle }\end{array}$ & Linacre & Kharrufa & Romanenko & Hargreaves & Makkink & Turc & Jensen-Haise & Penman \\
\hline 2014 & 0,055 & 0,191 & 0,053 & 0,181 & 0,400 & 0,800 & 0,806 & 0,836 & 0,794 \\
2015 & 0,061 & 0,103 & 0,050 & 0,085 & 0,199 & 0,801 & 0,812 & 0,843 & 0,789 \\
2016 & 0,214 & 0,266 & 0,254 & 0,124 & 0,303 & 0,789 & 0,804 & 0,881 & 0,776 \\
2017 & 0,081 & 0,177 & 0,074 & 0,117 & 0,235 & 0,762 & 0,754 & 0,801 & 0,708 \\
2018 & 0,153 & 0,216 & 0,165 & 0,074 & 0,314 & 0,740 & 0,760 & 0,829 & 0,727 \\
\hline
\end{tabular}

Nilai $\mathrm{R}^{2}$ menunjukan pengaruh variabel terikat terhadap variabel bebas yang di pengaruhi oleh nilai "a" pada persamaan linier $\mathrm{y}=\mathrm{a}+\mathrm{bx}$ dimana nilai 
$\mathrm{R}^{2}$ yang mendekati 1 yaitu pada model Makkink, Turc, Jensen- Haise, dan Penman. Adapun curah hujan rata - rata di stasiun Cut Nyak Dien Kabupaten Nagan Raya Aceh yaitu 4200 mm/tahun,

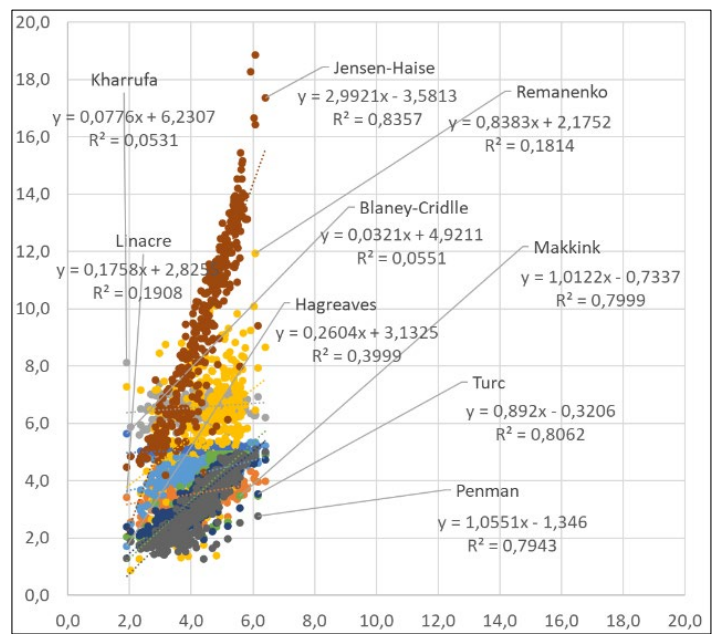

Gambar 1. Axis X Data Penman-

Monteith Axis Y Data Model Tahun $2014(\mathrm{~mm} /$ hari $)$

Dari gambar 1 dan 2 kita dapat melihat nilai "a" dan "b" pada nilai $\mathrm{y}=\mathrm{a}$ + bx yang mempengaruhi $\mathrm{R}^{2}$ dari masing - masing model, disini nilai "a" sangat mempengaruhi nilai dari regresi antara model - model dan model penman monteith. Jika kita melakukan set intercept dengan nilai $(\mathrm{x}, \mathrm{y})$ dengan nilai $(0,0)$, maka nilai "a" diabaikan atau sama dengan 0 , maka pengaruh data antara $\mathrm{x}$ dan $\mathrm{y}$ tidak dipangaruhi oleh nilai "a", sehingga hubungan antara data model - model dengan model penman monteith hanya berpengaruh antara sesama data model. sehingga nilai $\mathrm{y}=\mathrm{a}+\mathrm{bx}$ kita dapat lihat pada gambar $1-2$, dimana hujan dengan curah hujan rata - rata $4200 \mathrm{~mm} /$ tahun ini terjadi di tahun 2014, 2015, dan 2017.

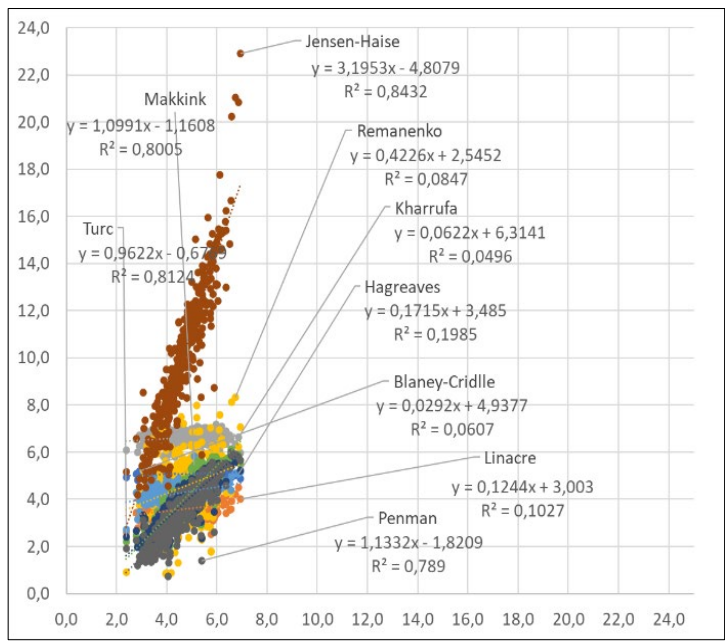

Gambar 2. Axis X Data PenmanMonteith -Axis Y Data Model Tahun 2015 (mm/hari)

Jika nilai $\mathrm{R}^{2}$ memiliki intercept $(\mathrm{x}, \mathrm{y})$ adalah $(0,0)$ maka didapatkan nilai dari $\mathrm{R}^{2}$ yang lebih baik, karena regresi hanya bersarkan nilai antara $\mathrm{x}$ dan $\mathrm{y}$. Kita dapat melihat nilai berikut pada gambar 3-6 dimana $\mathrm{R}^{2}$ pada model dengan intercept 0,0 di tahun 2015 - 2018 yang memiliki nilai konstan. Data $\mathrm{R}^{2}$ dengan set intercept $(0,0)$ dapat kita lihat pada tabel 3 yang dimana keseragaman regresi lebih baik jika hubungan antar model tidak dipengaruhi oleh nilai lain pada $\mathrm{y}=$ $\mathrm{a}+\mathrm{bx}$. 


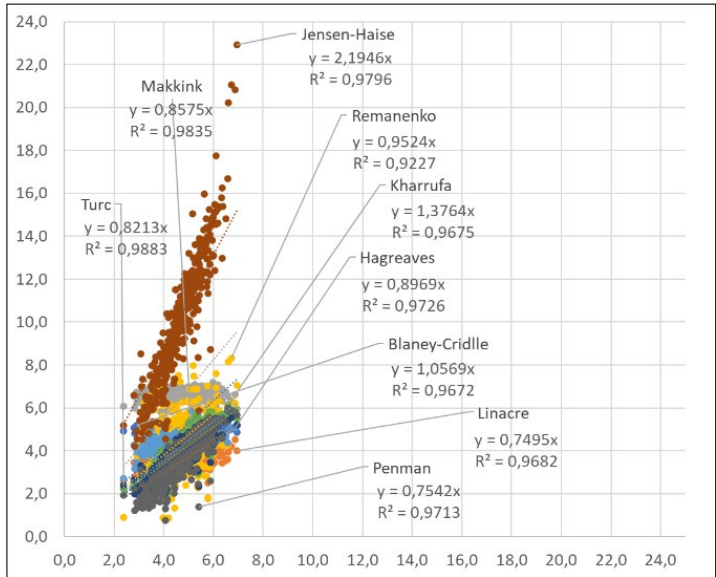

Gambar 3. Axis X Data PenmanMonteith - Axis Y Data Model Tahun 2015 ( $\mathrm{mm} /$ hari) set intercept $(0,0)$

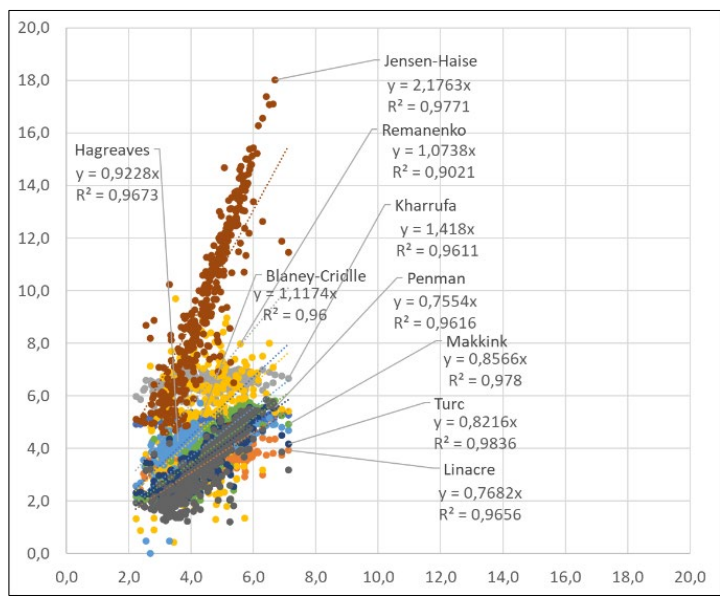

Gambar 5. Axis X Data PenmanMonteith - Axis Y Data Model Tahun $2017(\mathrm{~mm} /$ hari) set intercept $(0,0)$

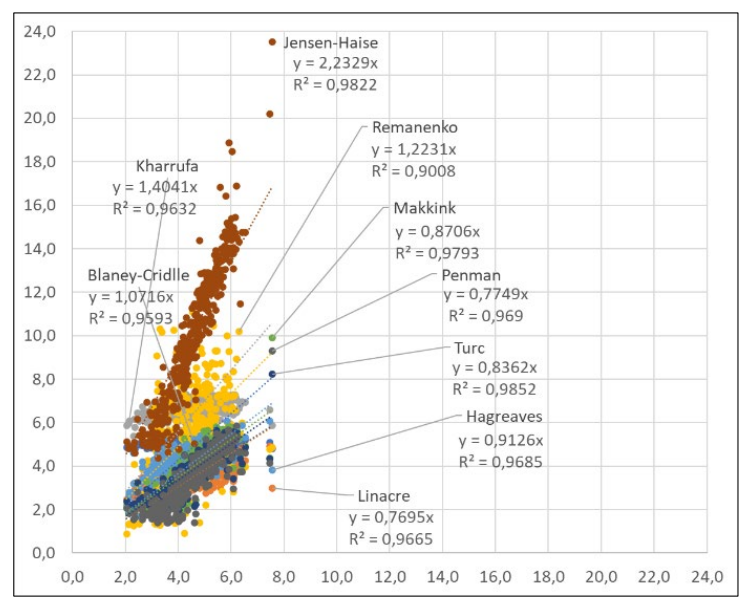

Gambar 4. Axis X Data PenmanMonteith - Axis Y Data Model Tahun $2016(\mathrm{~mm} / \mathrm{hari})$ set intercept $(0,0)$

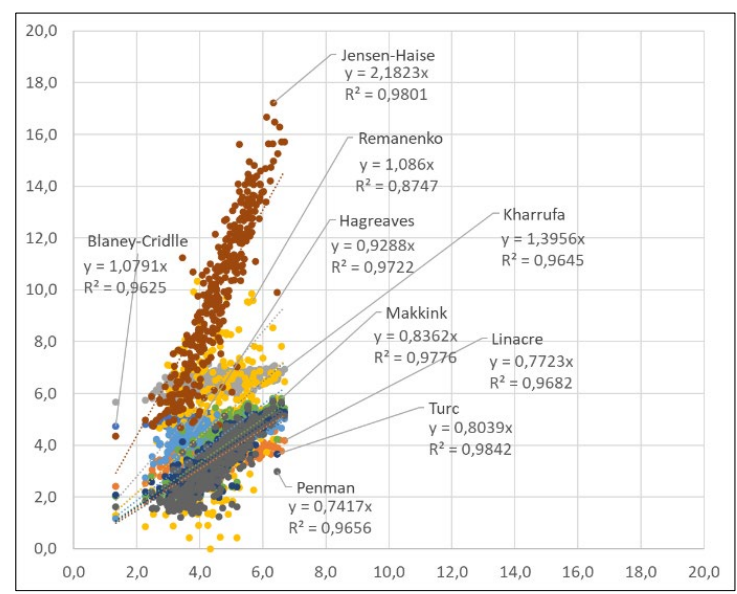

Gambar 6. Axis X Data PenmanMonteith - Axis Y Data Model Tahun $2018(\mathrm{~mm} /$ hari) set intercept $(0,0)$

Tabel 3. Nilai R2 antara Model - model dengan Model Penman - Monteith di Hujan 4200 $\mathrm{mm} /$ tahun set intercept $(0,0)$

\begin{tabular}{cccccccccc}
\hline YY & $\begin{array}{c}\text { Blaney- } \\
\text { Cridlle }\end{array}$ & Linacre & Kharrufa & Romanenko & Hargreaves & Makkink & Turc & $\begin{array}{c}\text { Jensen- } \\
\text { Haise }\end{array}$ & Penman \\
\hline 2015 & 0,967 & 0,968 & 0,967 & 0,922 & 0,972 & 0,983 & 0,988 & 0,979 & 0,971 \\
2016 & 0,959 & 0,966 & 0,963 & 0,901 & 0,968 & 0,979 & 0,985 & 0,982 & 0,969 \\
2017 & 0,960 & 0,965 & 0,961 & 0,902 & 0,967 & 0,978 & 0,983 & 0,977 & 0,961 \\
2018 & 0,962 & 0,968 & 0,964 & 0,874 & 0,972 & 0,977 & 0,984 & 0,980 & 0,965 \\
\hline
\end{tabular}

Data harian dari masing-masing variabel pada waktu 10 tahun $(2010-$ 2019) telah di olah dengan pemodelan pada software Microsoft Excel dengan bahasa program visual basic. Hasil yang didapatkan dari setiap metode -metode yang memiliki nilai $\mathrm{R}^{2}$ yang paling tinggi yaitu Makkink, Turc, JensenHaise, dan Penman (pada tabel 2), sedangkan $\mathrm{R}^{2}$ dengan set intercept $(0,0)$ model yang memiliki nilai paling tinggi yaitu model Hargreaves, Makkink, Turc, 
Jensen-Haise, dan Penman (pada tabel $3)$.

Setelah mengetahui nilai $\mathrm{R}^{2}$ dari masing-masing metode maka diketahui bahwa metode Hargreaves, Makkink, Turc, Jensen-Haise, dan Penman memiliki pengaruh besar terhadap metode Penman-Monteith, akan tetapi disini penulis juga melakukan pengambilan data perbandingan lain yaitu nilai RMSE, MAE, COVARIANCE, dan LOG sebagai nilai penentuan model yang paling mendekati dengan Panman - Monteith rekomendasi FAO.

Data RMSE dan MAE yang mendekati nilai 0 adalah data yang memiliki peluang kesalahan terkecil dengan akurasi yang baik. Adapun metode yang memiliki nilai error mendekati 0 dapat kita lihat pada tabel 4 dan 5. Pada tabel menunjukan bahwa model yang mendekati penman monteith adalah model yang memiliki nilai RMSE dan MAE terkecil.

Tabel 4. Nilai RMSE antara Model - model dengan Model Penman - Monteith di Hujan $4200 \mathrm{~mm} /$ tahun

\begin{tabular}{cccccccccc}
\hline YY & $\begin{array}{c}\text { Blaney- } \\
\text { Cridlle }\end{array}$ & Linacre & Kharrufa & Romanenko & Hargreaves & Makkink & Turc & $\begin{array}{c}\text { Jensen- } \\
\text { Haise }\end{array}$ & Penman \\
\hline 2015 & 0,957 & 1,346 & 2,140 & 1,321 & 0,862 & 0,853 & 0,944 & 5,835 & 1,312 \\
2016 & 1,081 & 1,261 & 2,273 & 2,157 & 0,867 & 0,843 & 0,900 & 5,901 & 1,231 \\
2017 & 1,165 & 1,242 & 2,298 & 1,641 & 0,846 & 0,875 & 0,943 & 5,552 & 1,305 \\
2018 & 1,042 & 1,226 & 2,191 & 1,925 & 0,791 & 0,949 & 1,013 & 5,605 & 1,347 \\
\hline
\end{tabular}

Tabel 5. Nilai MAE antara Model - model dengan Model Penman - Monteith di Hujan $4200 \mathrm{~mm} /$ tahun

\begin{tabular}{cccccccccc}
\hline YY & $\begin{array}{c}\text { Blaney- } \\
\text { Cridlle }\end{array}$ & Linacre & Kharrufa & Romanenko & Hargreaves & Makkink & Turc & $\begin{array}{c}\text { Jensen- } \\
\text { Haise }\end{array}$ & Penman \\
\hline 2015 & 0,050 & 0,070 & 0,112 & 0,069 & 0,045 & 0,045 & 0,049 & 0,305 & 0,069 \\
2016 & 0,057 & 0,066 & 0,119 & 0,113 & 0,045 & 0,044 & 0,047 & 0,309 & 0,064 \\
2017 & 0,061 & 0,065 & 0,120 & 0,086 & 0,044 & 0,046 & 0,049 & 0,291 & 0,068 \\
2018 & 0,055 & 0,064 & 0,115 & 0,101 & 0,041 & 0,050 & 0,053 & 0,293 & 0,071 \\
\hline
\end{tabular}

Berdasarkan evaluasi nilai RMSE dan MAE metode yang paling baik yaitu metode Hargreaves, Makkink, Turc, Blaney-Cridlle dan Penman. Melalui evaluasi ini kita juga dapat menyimpulan bahwa setiap metode juga memiliki kekurangan dan kelebihan seperti metode Jensen-Haise. Metode JensenHaise memiliki nilai $\mathrm{R}^{2}$ terbaik, tetapi memiliki nilai error yang tinggi. Selanjutnya evaluasi yang kita lakukan berdasarkan nilai COVARIANCE dan $L O G$ dapat kita lihat pada tabel 6 dan 7.

Tabel 6. Nilai COVARIANCE antara Model - model dengan Model Penman - Monteith di Hujan $4200 \mathrm{~mm} / \mathrm{tahun}$

\begin{tabular}{cccccccccc}
\hline YY & $\begin{array}{c}\text { Blaney- } \\
\text { Cridlle }\end{array}$ & Linacre & Kharrufa & Romanenko & Hargreaves & Makkink & Turc & $\begin{array}{c}\text { Jensen- } \\
\text { Haise }\end{array}$ & Penman \\
\hline 2015 & 0,022 & 0,095 & 0,048 & 0,323 & 0,131 & 0,840 & 0,736 & 2,443 & 0,866 \\
2016 & 0,062 & 0,241 & 0,173 & 0,675 & 0,275 & 1,056 & 0,931 & 3,009 & 1,052 \\
2017 & 0,023 & 0,139 & 0,064 & 0,523 & 0,248 & 0,914 & 0,775 & 2,507 & 0,905 \\
2018 & 0,040 & 0,161 & 0,100 & 0,474 & 0,240 & 0,865 & 0,757 & 2,512 & 0,878 \\
\hline
\end{tabular}


Tabel 7. Nilai LOG antara Model - model dengan Model Penman - Monteith di Hujan $4200 \mathrm{~mm} /$ tahun

\begin{tabular}{cccccccccc}
\hline YY & $\begin{array}{c}\text { Blaney- } \\
\text { Cridlle }\end{array}$ & Linacre & Kharrufa & Romanenko & Hargreaves & Makkink & Turc & $\begin{array}{c}\text { Jensen- } \\
\text { Haise }\end{array}$ & Penman \\
\hline 2015 & 0,095 & 0,134 & 0,180 & 0,151 & 0,080 & 0,105 & 0,109 & 0,329 & 0,177 \\
2016 & 0,113 & 0,125 & 0,198 & 0,182 & 0,084 & 0,106 & 0,106 & 0,335 & 0,166 \\
2017 & 0,120 & 0,126 & 0,201 & 0,168 & 0,122 & 0,113 & 0,113 & 0,327 & 0,182 \\
2018 & 0,109 & 0,124 & 0,192 & 0,195 & 0,077 & 0,120 & 0,121 & 0,328 & 0,185 \\
\hline
\end{tabular}

Adapun evaluasi ini dilakukan pada data stasiun klimatologi Cut Nyak Dien Kabupaten Nagan Raya Aceh yang memiliki iklim tropis, maka kita dapat dikatakan secara garis besar bahwa metode - metode terbaik yang dapat digunakan di iklim tropis khusunya wilayah Aceh selain metode yang direkomendasi oleh FAO (Metode Penman - Monteith) adalah metode Hargreaves, Makkink, Turc, BlaneyCridlle dan Penman. Jika diurutan berdasarkan ranking hasil evaluasi maka metode yang paling mendekati dengan metode Penman - Monteith yaitu Hargreaves, karena dari semua variabel evaluasi Hargreaves memiliki nilai evaluasi terbaik.

Pada penelitian yang dilakukan oleh Karo (2020) di Desa Semangat Kecamatan Merdeka, Kabupaten Karo, Sumatra Utara hasil laju evapotraspirasi menggunakan metode Hargreaves sebaran data yang didapatkan tidak seragam, sehingga regresi data yang tidak dilakukan set intercept memiliki nilai rendah, akan tetapi pada penelitian yang dilakukan Suprayogi, et al. (2003), metode Hargreaves sangat baik digunakan pada daerah aliran sungai, sebagai prediksi peluang kehilangan air, karena faktor yang ditekankan pada peneletian tersebut adalah variabel terperatur udara dan radiasi matahari. Hal ini menunjukkan kesamaan pada pemodelan yang dilakukan oleh penulis saat ini.

Penggunaan metode pendugaan laju evapotraspirasi sangat bergantung pada data yang didapatkan, dimana banyak sekali wilayah yang tidak memiliki stasiun klimatologi BMKG dari luasnya wilayah suatu daerah, ini dapat kita lihat pada peta stasiun klimatologi BNKG (dataonline.bmkg.go.id) terkadang banyak sekali faktor kejadian yang tidak dapat mewakili variabel data, sehingga kita perlu melakukan pengukuran diwilayah tersebut. Akan tetapi dengan keterbatasan alat pengukuran kita perlu suatu metode yang sesuai dengan alat yang digunakan.

Prediksi nilai laju evapotraspirasi dalam suatu wilayah harus kita lakukan dengan sebaik mungkin agar kesalahan pengambilan keputusan dari hasil pendugaan laju evapotraspirasi tidak terjadi (Manik, et al. 2012). Hasil pendugaan laju evapotraspirasi adalah suatu hal yang harus digaris bawahi sebagai hal yang penting. Hal ini terkait kerugian yang bisa ditimbulkan akibat kesalahan didalam prediksi nilai dari laju evapotraspirasi. Sehingga disini kita juga akan melakukan evaluasi pada kondisi ekstrem seperti pada musim panas dan hujan tinggi. Hasil evaluasi dapat dilihat pada tabel 8 dan 9 . 
Tabel 8. Evaluasi antara Model - model dengan Model Penman - Monteith di Tahun Kering (2019)

\begin{tabular}{cccccccccc}
\hline & $\begin{array}{c}\text { Blaney- } \\
\text { Cridlle }\end{array}$ & Linacre & Kharrufa & Romanenko & Hargreaves & Makkink & Turc & $\begin{array}{c}\text { Jensen- } \\
\text { Haise }\end{array}$ & Penman \\
\hline R2 & 0,171 & 0,209 & 0,191 & 0,051 & 0,254 & 0,735 & 0,752 & 0,830 & 0,695 \\
MAE & 0,048 & 0,070 & 0,111 & 0,116 & 0,043 & 0,045 & 0,050 & 0,312 & 0,067 \\
COV & 0,038 & 0,143 & 0,100 & 0,371 & 0,182 & 0,761 & 0,675 & 2,198 & 0,762 \\
RMSE & 0,920 & 1,332 & 2,121 & 2,218 & 0,831 & 0,864 & 0,955 & 5,961 & 1,288 \\
LOG & 0,091 & 0,132 & 0,177 & 0,177 & 0,078 & 0,101 & 0,106 & 0,338 & 0,164 \\
\hline
\end{tabular}

Tabel 9. Evalusi antara Model - model dengan Model Penman - Monteith di Tahun Basah (2010)

\begin{tabular}{cccccccccc}
\hline & $\begin{array}{c}\text { Blaney- } \\
\text { Cridlle }\end{array}$ & Linacre & Kharrufa & Romanenko & Hargreaves & Makkink & Turc & $\begin{array}{c}\text { Jensen- } \\
\text { Haise }\end{array}$ & Penman \\
\hline R2 & 0,085 & 0,223 & 0,150 & 0,129 & 0,303 & 0,583 & 0,570 & 0,607 & 0,477 \\
MAE & 0,068 & 0,051 & 0,130 & 0,138 & 0,051 & 0,065 & 0,067 & 0,302 & 0,087 \\
COV & 0,035 & 0,203 & 0,120 & 0,702 & 0,201 & 0,788 & 0,671 & 2,445 & 0,708 \\
RMSE & 1,290 & 0,983 & 2,492 & 2,631 & 0,978 & 1,242 & 1,275 & 5,764 & 1,658 \\
LOG & 0,150 & 0,111 & 0,233 & 0,217 & 0,119 & 0,152 & 0,151 & 0,357 & 0,222 \\
\hline
\end{tabular}

Pada kondisi ekstrem model Hargreaves, Makkink, Turc, dan Penman masih konsisten dengan hasil yang baik. Hasil model Hargreaves di saat tahun kering dengan hujan $3530 \mathrm{~mm} / \mathrm{tahun}$ memiliki nilai MAE, RMSE, COV, dan LOG terbaik yaitu 0,$043 ; 0,182 ; 0,831$; dan 0,078 . Sedangkan di musim hujan dengan hujan $5015 \mathrm{~mm} /$ tahun yaitu 0,$051 ; 0.201 ; 0,978$; dan 0,119 .

Kita dapat melihat dari sepuluh metode pendugaan laju evapotraspirasi dengan data dan alat pengukuran yang sama tidak sepenuhnya memiliki nilai yang sama, bahkan memiliki nilai yang beragaman di setiap waktunya, hal ini menujukkan setiap metode memiliki kelebihan dan kekurangannya masing masing, sehingga peneliti harus cermat didalam mengambil keputusan didalam penggunaan suatu metode pendugaan laju evapotranspirasi.

Pembuktian dari hasil model yang telah dievaluasi tersebut dapat dilihat pada kondisi normal di tabel 10 dan kondisi ekstrem pada tabel 11. Disana telah terdapat hasil dari pembobotan keseluruhan variabel yang menjadi parameter evaluasi.

Tabel 10. Overall antara Model - model dengan Model Penman - Monteith di Hujan 4200 $\mathrm{mm} /$ tahun

\begin{tabular}{cccccccccc}
\hline YY & $\begin{array}{c}\text { Blaney- } \\
\text { Cridlle }\end{array}$ & Linacre & Kharrufa & Romanenko & Hargreaves & Makkink & Turc & $\begin{array}{c}\text { Jensen- } \\
\text { Haise }\end{array}$ & Penman \\
\hline 2015 & 0,457 & 0,325 & 0,205 & 0,270 & 0,523 & 0,484 & 0,490 & 0,102 & 0,363 \\
2016 & 0,447 & 0,364 & 0,220 & 0,164 & 0,500 & 0,431 & 0,451 & 0,098 & 0,347 \\
2017 & 0,380 & 0,364 & 0,193 & 0,211 & 0,477 & 0,447 & 0,462 & 0,102 & 0,339 \\
2018 & 0,448 & 0,376 & 0,217 & 0,176 & 0,559 & 0,433 & 0,449 & 0,104 & 0,341 \\
\hline
\end{tabular}


Tabel 11. Overall antara Model - model dengan Model Penman - Monteith di Kondisi Ekstrem

\begin{tabular}{ccccccccccc}
\hline YY & $\begin{array}{c}\text { Blaney- } \\
\text { Cridlle }\end{array}$ & Linacre & Kharrufa & Romanenko & Hargreaves & Makkink & $\begin{array}{c}\text { Turc } \\
\text { Haise }\end{array}$ & $\begin{array}{c}\text { Jensen- } \\
\text { Penman }\end{array}$ \\
\hline Kering & 0,520 & 0,353 & 0,232 & 0,165 & 0,542 & 0,485 & 0,487 & 0,106 & 0,365 \\
Basah & 0,334 & 0,437 & 0,185 & 0,141 & 0,467 & 0,345 & 0,356 & 0,091 & 0,266 \\
\hline
\end{tabular}

Pada hasil perhitungan Overall dari variabel evaluasi model didapatkan nilai pembobotan terbaik yaitu model Hargreaves, Makkink, Turc, dan BlaneyCridlle. Melalui model evaluasi yang dilakukan oleh penulis model terbaik yang mendekati model Penman Monteith adalah Model Hargreaves.

Berdasarkan data yang saya peroleh dari hasil evaluasi, maka setiap wilayah dengan iklim yang berbeda seperti wilayah tropis, subtropis, sedang, dan dingin pasti memiliki kecocokan tertentu didalam pendugaan laju evapotraspirasi yang ada saat ini, bahkan didalam wilayah yang miliki iklim yang sama juga masih perlu pertimbangan, khusus didalam penentuan metode pendugaan laju evapotraspirasi. Hal ini disebabkan faktor variabel dari setiap metode pendugaan laju evapotranspirasi tersebut.

\section{KESIMPULAN}

Model-model yang paling mendekati model penman - monteith untuk studi khasus data klimatologi Cut Nyak Dien Kabupaten Nagan Raya Aceh dengan pertimbangan evaluasi nilai $\mathrm{R}^{2}$, RMSE, MAE, COVARIANCE, dan LOG adalah model Hargreaves, Makkink, Turc, Blaney-Cridlle dan Penman. Jika diurutan berdasarkan ranking hasil evaluasi, maka hasil perhitungan yang paling mendekati dengan model Penman - Monteith yaitu model Hargreaves, karena dari semua variabel evaluasi model Hargreaves memiliki nilai evaluasi terbaik dalam menentukan laju evapotranspirasi yang mendekati Penman - Monteith.

\section{DAFTAR PUSTAKA}

Berengena, J dan P. Gavilan. 2005. Reference Evapotranspiration Estimation in a Highly Advective Semiarid Environment. Journal of Irrigation and darinage Engineering. 131(2): $147-163$

Blaney H.F., dan W. D. Criddle. 1962. Determining Consumptive Use and Irrigation Water Requirements. U.S. Government Printing Office, Washington D.C.

[BMKG]

http://www.dataonline.bmkg.go.id (diakses 2020)

Cepece J.C, Catteneo D, Lim Y.S, Rodriguez E.E, Upham L, Campbel K.L.2002. Comparison of Evapotranspiration Estimation Methods.

Doorenbos J dan Pruitt W.O. 1977. Guideline for Predicting Crop Water Requirement. FAO. Rome.144 p

Fibriana, R, Ginting, Y.S, Ferdiansyah, E, Mubarak, S. 2018. Analisis Besar Atau Laju Evapotranspirasi pada Daerah Terbuka. Agrotekma, 2 (2): 130 - 137

Hargreaves, G. H. 1982. Estimation of potential evapotranspiration. Journal of Irrigation and Drainage Division, Proceedings of the American Society of Civil Engineers 108: 223-230

Karo, V.B. Riska. 2020. Kajian Beberapa Metode Perhitungan Nilai Evapotranspirasi Potensial (Studi Kasus Desa Semangat 
Kecamatan Merdeka Kabupaten Karo). Program Studi Keteknikan Pertanian. Universitas Sumatra Utara.

Kharrufa, N. 1985. Simplified equation for evapotranspiration in arid regions. Beiträge Hydrol 5: 39-47

Manik, T K., R. B. Rosadi dan A. Karyanto. 2012. Evaluasi Metode Penman-Monteith dalam Menduga Laju Evapotranspirasi Standar (ET0) di Dataran Rendah Propinsi Lampung, Indonesia. Jurnal Keteknikan Pertanian. 26 (2): 121 $-128$

Romanenko, V. A. 1961. Computation of the autumn soil moisture using a universal relationship for a large area. Proc. Ukrainian Hydrometeorological Res. Inst. (Kiev) 3

Runtunuwu, E, Syahbuddin, H, dan Pramudia, A. 2008. Validasi Model Pendugaan Evapotranspirasi: Upaya Melengkapi Sistem Database Iklim Nasional. Jurnal Tanah Dan Iklim 27: 1-8

Suprayogi, S, Setiawan I.B., dan Prasetyo, L.B. 2003. Penerapan Beberapa Model Evapotranspirasi Di Daerah Tropika. Buletin Keteknikan Pertanian. 17 (2): 7 13.

Saidah, H, Sulistyono, H, Budianto, M. B. 2020. Kalibrasi Persamaan Thornthwaite dan Evaporasi Panci Untuk Memprediksi Evapotranspirasi Potensial Pada Daerah Dengan Data Cuaca Terbatas. Jurnal Sains Teknologi \&Lingkungan 6 (1): 72-84

Steduto, P., M. Todorovic, A. Caliandro, dan P. Rubino. 2003. Daily Reference Evapotranspiration Estimates by The Penman-
Monteith Equation in Southern Italy. Constant Vs. Variabel Canopy Resistance. Theor. Appl. Climatol. 74: 217-225

Temesken, B., S. Eching, B. Davidoff dan K. Frame. 2005. Comparison of Some Reference Evapotranspiration Equations for California. Journal of Irrigation and Drainage Engineering 131 (1):73-84 
JSIL | Adlan dkk. : Evaluasi Metade Pendugaan Laju Evapotranspirasi Standar (ETo) 